\title{
ANALISIS FAKTOR-FAKTOR YANG MEMPENGARUHI PENGUKURAN PENGUNGKAPAN CORPORATE SOCIAL RESPONSIBILITY (CSR) PERBANKAN SYARIAH BERDASARKAN INDEKS ISLAMIC SOCIAL REPORTING (ISR)
}

\author{
Susi Astuti \\ email: susieastuti@gmail.com
}

\begin{abstract}
The Corporate Social Responsibility (CSR) program is an investment for companies for the growth and sustainability of the company and is no longer seen as a cost center but as a means to become a profit center.

The implementation of CSR in banking industry has the goal of making CSR as one of the companies to regulate their business not only for the benefit of shareholders but for other stakeholders. In addition, Corporate Social Responsibility (CSR) is also a challenge to maintain the company's reputation in the community.

The issue of Corporate Social Responsibility (CSR) sticking out along with the development of a banking sector related to the need for disclosure of social responsibility in Islamic banking today, is widely discussed about the Islamic Social Reporting Index (ISR index). The ISR index contains compilation of standard items of CSR set by AAOIFI which were further developed by researchers regarding CSR items that should be disclosed by an Islamic entity. The Islamic Social Reporting (ISR) index is believed to be the initial benchmark in terms of disclosure standards for Corporate Social Responsibility (CSR) that are in accordance with the Islamic perspective. This research was conducted on Islamic banks in the Middle East region whose annual reports were announced through banking sites using a sample of Islamic bank annual reports published during the period 2015-2017.
\end{abstract}

Keyword: Corporate Social Responsibility (CSR), Islamic Banking, Islamic Social Reporting (ISR) Index

\section{PENDAHULUAN}

\section{Latar Belakang Masalah}

Tanggungjawab sosial atau Corporate Social Responsibility (CSR) muncul karena adanya kebutuhan entitas bisnis untuk memperhatikan lingkungan sosialnya. Hal tersebut dipicu oleh tren yang berkaitan dengan praktek Corporate Social Responsibility (CSR) dalam bisnis. Entitas bisnis tidak hanya memikirkan dan bertanggungjawab terhadap pencapaian keuntungan atau laba semata, tetapi juga harus memperhatikan aspek sosial dan lingkunga entitas bisnis.

Program Corporate Social Responsibility (CSR) tidak lagi dipandang sebagai pusat biaya (cost centre), tetapi juga dijadikan sebagai sarana untuk menjadi pusat laba (profit centre).

Corporate Social Responsibility (CSR) merupakan komitmen untuk menciptakan pertumbuhan dan mendukung pembangunan berkelanjutan (sustainable development). Konsep ini dibangun atas tiga pilar yang saling berhubungan satu dengan lainnya, yaitu sosial, ekonomi, dan lingkungan.

Industri perbankan termasuk salah satu entitas bisnis yang diwajibkan untuk melakukan Corporate Social Responsibility (CSR). Implementasi kegiatan Corporate Social Responsibility (CSR) untuk memenuhi kebutuhan pemegang saham dan pemangku kepentingan lainnya. Selain itu, dengan 
pelaksanaan Corporate Social Responsibility (CSR) dapat mempertahankan reputasi perusahaan di masyarakat yang berada di lingkungan perusahaan.

Dalam pandangan perbankan konvensional, pelaporan Corporate Social Responsibility (CSR) ditujukan pada pengguna laporan keuangan dan laporan tahunan perbankan. Pihak-pihak yang berkepentingan terhadap laporan keuangan diantaranya adalah pemegang saham, pelanggan, pemasok, karyawan, dan masyarakat di lingkungan sekitar.

Sudut pandang perbankan konvensional masih menganggap bahwa pelaporan Corporate Social Responsibility (CSR) hanya ditujukan pada dimensi hubungan horizontal, yaitu hubungan antarmanusia yang berfokus pada aspek material dan moral.

Berbeda halnya dengan pelaporan tanggungjawab sosial dalam perspektif syariah, perbankan syariah perlu memfokuskan diri pada aspek spiritual pada pelaporan tanggungjawab sosialnya yang sesuai dengan prinsip Islam.

Praktek pengungkapan Corporate

Social Responsibility (CSR) pada perbankan syariah cukup relevan ditinjau dari sisi sifat. Dalam menjalankan kegiatan operasionalnya, perbankan syariah berlandaskan pada prinsip syariah serta berdasarkan pada filosofi dasar AlQuran dan Al-Hadist.

Isu Corporate Social Responsibility (CSR) mulai muncul seiring dengan kebutuhan perbankan syariah untuk mengungkapkan tanggungjawab sosial dengan menggunakan Indeks Islamic Social Reporting (ISR). adalah:

Batasan masalah pada penelitian ini

1. Penelitian ini menggunakan objek bank syariah di kawasan Timur Tengah yang laporan tahunannya diumumkan melalui situs perbankan.

2. Penelitian ini menggunakan sampel laporan tahunan bank syariah yang dipublikasikan selama periode 2012 2014.

Rumusan masalah dalam penelitian ini:

1. Bagaimana pengaruh karakteristik Dewan Pengawas Syariah (DPS) terhadap pengungkapan Corporate Social Responsibility (CSR) pada perbankan syariah di kawasan Timur Tengah?

2. Bagaimana pengaruh kinerja keuangan terhadap pengungkapan Corporate Social Responsibility (CSR) pada perbankan syariah di kawasan Timur Tengah?

Adapun tujuan dari penelitian ini adalah sebagai berikut:

1. Menguji dan menganalisis pengaruh karakteristik Dewan Pengawas Syariah (DPS) terhadap pengungkapan Corporate Social Responsibility (CSR) pada perbankan syariah di kawasan Timur Tengah.

2. Menguji dan menganalisis pengaruh kinerja keuangan terhadap pengungkapan Corporate Social Responsibility (CSR) pada perbankan syariah di kawasan Timur Tengah.

\section{Manfaat Penelitian}

Manfaat penelitian ini adalah sebagai berikut:

1. Bagi Pemerintah, hasil penelitian ini dapat digunakan sebagai evaluasi pembuatan regulasi tentang pengungkapan Corporate Social Responsibility (CSR) perbankan syariah sehingga sesuai dengan prinsip-prinsip Islam.

2. Bagi masyarakat, hasil penelitian ini dapat digunakan untuk memberi pemahaman bahwa Corporate Social Responsibility (CSR) bukan hanya aspek moral, materi, dan etika melainkan didalamnya terkandung aspek spiritual.

3. Bagi perbankan syariah, hasil penelitian ini dapat digunakan sebagai bahan pertimbangan untuk menjadikan Islamic Social Reporting (ISR) sebagai 
acuan dan tolok ukur yang memadai dalam melaksanakan dan pengungkapan Corporate Social Responsibility (CSR).

4. Bagi peneliti dan mahasiswa, hasil penelitian ini digunakan untuk menambah pemahaman mengenai pengungkapan Corporate Social Responsibility (CSR) berdasarkan Islamic Social Reporting (ISR) pada perbankan syariah dan juga dapat dikembangkan serta dijadikan sebagai acuan pada penelitian berikutnya.

\section{KAJIAN PUSTAKA \\ Landasan Teori Agency Theory (Teori Agensi)}

Teori agensi didasari hubungan antar anggota-anggota dalam perusahaan yang terikat kontrak. Anggota-anggota itu disebut sebagai prinsipal dan agen. Prinsipal dan agen merupakan pelaku utama dalam kontrak tersebut. Prinsipal adalah pihak yang memberikan tanggungjawab kepada agen untuk bertindak atas nama prinsipal. Agen merupakan pihak yang bertanggungjawab untuk melakukan tindakan atas nama prinsipal.

\section{Stakeholders Theory}

Menurut Friedman (1967) dalam Muamar (2014), tugas perusahaan adalah memaksimalkan keuntungan demi pemegang sahamnya dan apabila perusahaan melakukan aktivitas Corporate Social Responsibility (CSR) diluar kepentingan stakeholders, maka hal itu akan menyalahi tujuan utama perusahaan.

Dalam teori ini disebutkan bahwa pengungkapan Corporate Social Responsibility (CSR) merupakan cara untuk menyampaikan informasi kepada stakeholders. Implikasinya adalah entitas bisnis akan secara sukarela melaksanakan Corporate Social Responsibility (CSR) karena pelaksanaan itu merupakan bagian dari peran dan tanggungjawab entitas bisnis kepada stakeholders.

\section{Perkembangan Bank Syariah}

Pada abad XIX dan XX Masehi muncul suatu gerakan yang dikenal dengan Islamic Revivalism (gerakan kebangkitan Islam). Islamic Revivalism menentang sistem pemberian bunga yang dilakukan oleh bank konvensional ke negara-negara mayoritas Muslim. Gerakan Islamic Revivalism ini memicu munculnya gerakan modern (modernism) dan gerakan NeoRevivalis (neo-revivalism).

Konsep teoritis mengenai bank Islam muncul pertama kali pada tahun 1940-an yang memberi gagasan perbankan berdasarkan prinsip bagi hasil (profit-loss sharing). Maududi Uzair adalah perintis teori perbankan Islam. Karya Maududi Uzair yang berjudul A Ground Work For Interest Free Bank menyebutkan sistem bank tanpa bunga. Selanjutnya mulai bermunculan penulis lain yang mempunyai pemikiran yang sama tentang teori perbankan Islam, diantaranya adalah Mahmud Ahmad, Naiem Siddiqi, dan Anwar Qureshi.

Fenomena yang terjadi menyadarkan betapa pentingnya menerapkan prinsip dan nilai-nilai syariah. Banyak upaya yang bisa dilakukan, diantaranya adalah menerapkan prinsip Islam dalam lembaga keuangan syariah. Terbentuknya lembaga keuangan atau bank dengan prinsip syariah berawal dari keinginan umat Islam untuk menjalankan usahanya tidak menggunakan prinsip riba dan sesuai dengan aturan dalam Al-Quran dan As-Sunnah.

Sistem yang mendasari terbentuknya perbankan syariah atau perbankan Islam adalah larangan dalam Islam tentang riba dan investasi untuk usaha-usaha yang dikategorikan haram (misalnya usaha yang berkaitan dengan produksi makanan atau minuman haram, usaha media yang tidak Islami, dan lainnya), sehingga perlu dikembangkan sistem perbankan yang berdasarkan syariah (hukum) Islam. Sistem perbankan 
konvensional tidak dapat menjamin kegiatan tersebut.

\section{Regulasi Perbankan Syariah}

Seperti halnya perbankan konvensional, perbankan syariah juga membutuhkan regulasi dengan alasan sebagai berikut:

a. Risiko kebangkrutan perbankan syariah yang tidak bisa diabaikan.

b. Risiko kerugian ekonomi karena buruknya keputusan investasi, yang disebabkan adanya kombinasi berbagai faktor, misalnya lingkungan usaha yang rentan, lemahnya tata kelola internal, dan rendahnya disiplin pasar.

c. Sistem perbankan yang lemah dapat menurunkan kinerja makro ekonomi, misalnya efisiensi pembayaran dan efektivitas, kebijakan moneter serta dapat menurunkan tingkat kepercayaan publik terhadap sistem keuangan

d. Sistem perbankan yang lemah akan menghalangi perekonomian globalisasi dan liberalisasi pasar finansial domestik.

Regulasi perbankan syariah diharapkan dapat memberi kerangka untuk penetapan kebijakan, standar, kontrol, serta instrumen pengawasan yang baik dan efektif sesuai dengan syariah dan standar internasional. Kerangka pengawasan perbankan konvensional dapat dijadikan benchmark seperti ketentuan tentang kecukupan modal, pengelolaan likuiditas, tata kelola perusahaan, transparansi, disclosure, disiplin pasar, manajemen resiko, dan perlindungan konsumen.

\section{Dewan Pengawas Syariah (DPS)}

Eksistensi Dewan Pengawas Syariah (DPS) masih berdasarkan pendekatan konvensional. Permasalahan yang sering muncul dalam praktek penerapan Corporate Social Responsibility (CSR) adalah pengawasan terhadap kegiatan usaha bank syariah dan kewenangan serta fungsi Dewan Pengawas Syariah (DPS) terhadap kegiatan usaha bank syariah masih ada yang menyimpang dari prinsip syariah.

Anggota komite syariah diangkat berdasarkan rekomendasi yang sesuai dengan nominasinya dan seharusnya tidak boleh kurang dari 5 (lima) orang dan yang utamanya adalah orang-orang yang mempunyai pengetahuan tentang syariah yang sesuai dengan kualifikasinya.

Komite syariah bertanggungjawab terhadap semua keputusan, pandangan, dan pendapat yang berkaitan dengan permasalahan syariah. Komite syariah diharapkan dapat melakukan pengawasan terhadap permasalahan yang berkaitan dengan syariah pada kegiatan atau aktivitas operasional perbankan.

Institusi keuangan Islam tentunya menghasilkan laporan atau informasi yang harus diserahkan ke komite syariah sebelum informasi tersebut dipublikasikan. Tujuannya adalah untuk mendapatkan otorisasi terlebih dahulu.

\section{Perkembangan Corporate Social Responsibility (CSR) \\ Corporate Social Responsibility} (CSR) secara terus menerus dilaksanakan oleh entitas bisnis. Survei yang dilakukan oleh Global Reporting Initiative (2008) menunjukkan adanya peningkatan yang siginifikan atas jumlah entitas bisnis yang membuat laporan Corporate Social Responsibility (CSR), yaitu 300 entitas bisnis di tahun 1996 menjadi 3.100 entitas bisnis di tahun 2008. Selain itu, hasil survei memperlihatkan bahwa pelaporan Corporate Social Responsibility (CSR) dilakukan sebagai pelaporan yang bersifat sukarela.

Seiring dengan berkembangnya jaman, banyak organisasi internasional yang memberikan pedoman penyajian pelaporan Corporate Social Responsibility (CSR), diantaranya adalah Global Reporting Initiative Sustainability Reporting Guidelines (diterbitkan oleh Global Reporting Initiative (GRI)). Global Reporting Initiative (GRI) Sustainability Reporting Guidelines adalah standar 
pelaporan yang diterima secara umum dan paling banyak digunakan oleh perusahaanperusahaan di dunia.

\section{Indeks Islamic Social Reporting (ISR)}

Selain Global Reporting Initiative (GRI), mengukur pengungkapan Corporate Social Responsibility (CSR) menggunakan Indeks Islamic Social Reporting (ISR). Indeks Islamic Social Reporting (ISR) ini mereupakan kumpulan dari komponen standar Corporate Social Responsibility (CSR).

Indeks Islamic Social Reporting (ISR) ini juga merupakan alat ukur yang digunakan untuk mengukur pengungkapan Corporate Social Responsibility (CSR) pada entitas Islam dengan komponenkomponen sebagai berikut:

I. Tanggungjawab DPS (Dewan Pengawas Syariah), dibagi menjadi:

1. Nama anggota DPS dan kualifikasinya

2. Ruang lingkup pekerjaan dan penyesuaian terhadap ketentuan hokum

3. Review/lingkup pemeriksaan

4. Opini terhadap hasil pemeriksaan

5. Rekomendasi untuk perbaikan

6. Tanda tangan anggota DPS

7. Gaji/remunerasi DPS

II. Informasi Produk dan Jasa, dibagi menjadi:

1. Informasi mengenai produk dan jasa baru

2. Persetujuan produk baru dari DPS

3. Daftar/definisi produk yang ditawarkan

4. Informasi umum kegiatan investasi

5. Informasi umum dari kegiatan pembiayaan

III. Pengelolaan Zakat, dibagi menjadi:

1. Pernyataan sumber dan penggunaan dana zakat

2. Saldo dana zakat dan alasan belum didistribusikannya

3. Pengesahan mengenai perhitungan dan distribusi dana zakat

IV. Pinjaman Qardh Al-Hasan, dibagi menjadi:
1. Kebijakan bank dalam memberikan pinjaman Qardh

2. Sumber dana yang dialokasikan untuk Qardh

3. Jumlah yang diberikan kepada penerima manfaat

V. Kegiatan Amal dan Sosial, dibagi menjadi:

1. Sifat kegiatan amal dan sosial

2. Jumlah yang dikeluarkan untuk kegiatan ini

3. Sumber dana yang digunakan untuk membiayai kegiatan ini

VI. Transaksi yang melaanggar hukum (Haram), dibagi menjadi:

1. Alasan untuk menjalankan transaksi tersebut

2. Jumlah pendapatan atau beban dari transaksi ini

3. Kebijakan bank untuk menerima dan menyalurkan dana non halal

VII. Tanggungjawab Kepada Karyawan, dibagi menjadi:

1. Kebijakan gaji, pemberian upah dan kesejahteraan lainnya

2. Kebijakan pendidikan dan pelatihan karyawan

3. Kebijakan kesempatan yang sama diantara karyawan

4. Kebijakan di lingkungan kerja

5. Kegiatan pendidikan dan pelatihan karyawan

6. Apresiasi terhadap karyawan

7. Penghargaan karyawan (bonus, dll)

VIII. Tanggungjawab Kepada Masyarakat, dibagi menjadi:

1. Menciptakan kesempatan kerja

2. Dukungan untuk organisasi yang memberikan manfaat kepada masyarakat

3. Mensponsori kegiatan masyarakat

4. Pernyataan komitmen untuk peran sosial

5. Partisipasi pada konferensi/seminar tentang ekonomi syariah, perbankan dan keuangan

6. Magang untuk mahasiswa

IX. Aspek Pengembangan Komunitas Masyarakat, dibagi menjadi: 
1. Peran bank pada perkembangan ekonomi

2. Peran bank dalam menangani masalah sosial

3. Peran bank dalam menangani pengembangan pendidikan dan sponsor

4. Peran bank dan komitmen untuk memberikan pembiayaan bagi sektor ekonomi mikro dan kecil

X. Keterlambatan Pembayaran Oleh Klien dan Masalah Klien, dibagi menjadi:

1. Kebijakan dalam menangani klien yang memiliki masalah

2. Jumlah yang dibebankan sebagai penalty/denda, jika ada

3. Opini syariah mengenai diperbolehkannya membebankan biaya tambahan (seperti penalti/denda)

4. Pengakuan pembayaran penalti/denda sebagai sumber pendapatan lain

\section{Penelitian Terdahulu}

Penelitian terdahulu melakukan analisis tentang pengaruh jenis industri, ukuran perusahan, komposisi Dewan Pengawas Syariah (DPS), tekanan politik, regulasi pemerintah, dan lainnya terhadap pengungkapan Corporate Social Responsibility (CSR).

Tabel 1. Penelitian Terdahulu

\begin{tabular}{|l|l|l|}
\hline Penulis & $\begin{array}{l}\text { Data dan } \\
\text { Metodologi }\end{array}$ & $\begin{array}{c}\text { Hasil } \\
\text { Penelitian }\end{array}$ \\
\hline Muham & Data : & a. Keterlibata \\
mad. R. & Laporan & n para \\
(2010) & Keuangan & penyusun \\
& Perbankan & laporan \\
& Islam di & keuangan \\
& Malaysia. & dalam \\
& Akuntan & operasi \\
& Bank Islam & bank Islam \\
& (preparer) & lebih \\
& Pengguna & intensif \\
& Laporan & dibandingk \\
& Keuangan & an \\
& (user) yaitu & pengguna. \\
& anggota & b. Anggota \\
\hline
\end{tabular}

\begin{tabular}{|c|c|}
\hline $\begin{array}{l}\text { DPS, } \\
\text { akademisi } \\
\text { akuntansi } \\
\text { Muslim, } \\
\text { mahasiswa } \\
\text { pasca } \\
\text { sarjana } \\
\text { dari dalam } \\
\text { dan luar } \\
\text { perbankan } \\
\text { syariah }\end{array}$ & $\begin{array}{l}\text { DPS tidak } \\
\text { cukup } \\
\text { intensif } \\
\text { untuk } \\
\text { terlibat } \\
\text { dalam } \\
\text { bank } \\
\text { Islam, } \\
\text { tetapi } \\
\text { hanya } \\
\text { terlibat } \\
\text { dalam } \\
\text { permasalah } \\
\text { an syariah } \\
\text { c. Total nilai } \\
\text { rata-rata } \\
\text { tujuan } \\
\text { pelaporan } \\
\text { sosial dari } \\
\text { perspektif } \\
\text { Islam } \\
\text { menunjukk } \\
\text { an bahwa } \\
\text { pengguna } \\
\text { laporan } \\
\text { keuangan } \\
\text { cenderung } \\
\text { memiliki } \\
\text { harapan } \\
\text { lebih tinggi } \\
\text { daripada } \\
\text { penyusun } \\
\text { terhadap } \\
\text { penyampai } \\
\text { an isu-isu } \\
\text { sosial oleh } \\
\text { bank } \\
\text { Islam. } \\
\text { d. Penyusun } \\
\text { laporan } \\
\text { keuangan } \\
\text { bank Islam } \\
\text { dan } \\
\text { pengguna } \\
\text { memiliki } \\
\text { perbedaan } \\
\text { persepsi } \\
\text { sang } \\
\text { terhifadap }\end{array}$ \\
\hline
\end{tabular}




\begin{tabular}{|l|l|l|}
\hline & & $\begin{array}{l}\text { tujuan } \\
\text { pelaporan } \\
\text { sosial dari } \\
\text { perspektif } \\
\text { Islam. }\end{array}$ \\
\hline Sayd & Data: & a. Mekanisme \\
S., & Laporan & tata kelola \\
Hassan & Keuangan & yang \\
M.K., & 47 (empat & dilakukan \\
Lanis. & puluh tujuh) & oleh DPS \\
R. & bank dari 14 & Tingkat \\
(2011). & (empat & bebebasan \\
& belas) & politik dan \\
negara di & sosial \\
& Timur & menjadi \\
& Tengah & faktor \\
& & penentu \\
dalam \\
& & pengungka \\
& & pan CSR \\
\hline
\end{tabular}

\section{Hipotesis}

H1 : Pengaruh jumlah DPS terhadap Indeks ISR

$\mathrm{H} 2$ : Pengaruh jumlah DPS bergelar Doctor terhadap Indeks ISR

H3 : Pengaruh reputasi DPS terhadap Indeks ISR

H4 : Pengaruh rangkap jabatan DPS terhadap Indeks ISR

H5 : Pengaruh Non Performing Finance (NPF) terhadap Indeks ISR

H6 : Pengaruh Return On Equity (ROE) terrhadap Indeks ISR

H7 : Pengaruh Return On Investment (ROI) terhadap Indeks ISR

H8 : Pengaruh Capital Adequacy Ratio (CAR) terhadap Indeks ISR

H9 : Pengaruh kinerja operasional terhadap Indeks ISR

\section{Kerangka Pemikiran}

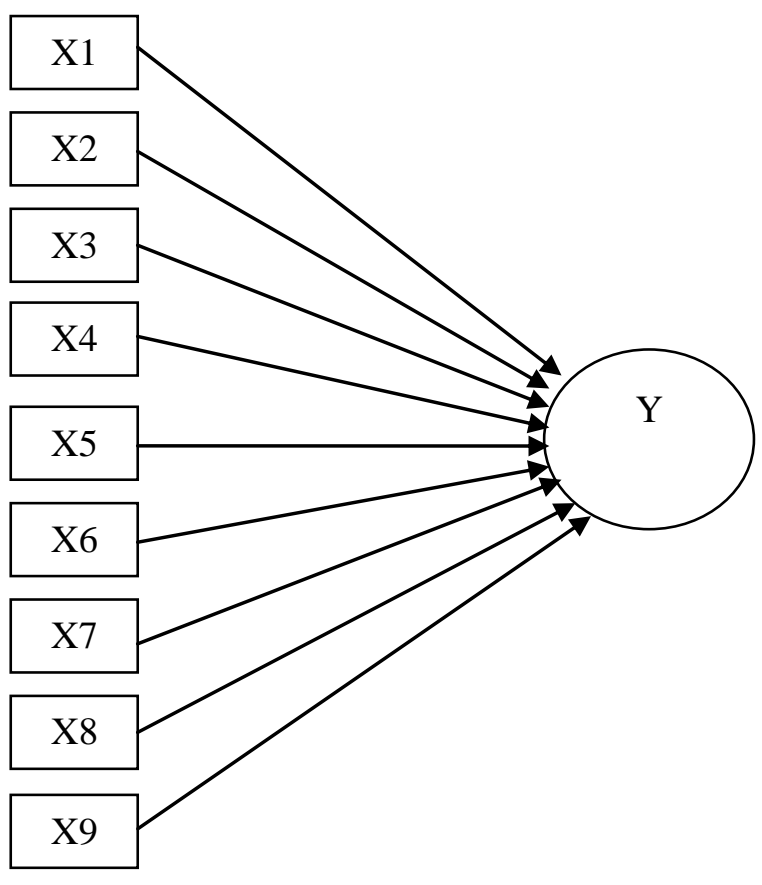

\section{METODE PENELITIAN}

\section{Populasi Dan Sampel Penelitian}

Populasi dari penelitian ini adalah bank syariah di kawasan Timur Tengah dengan aset terbesar yang dipublikasikan oleh Maris Strategies \& The Banker tahun 2013.

Adapun bank yang dijadikan sebagai populasi dan sampel penelitian adalah:

1. Al Salam Bank, negara Bahrain

2. Bahrain Islamic Bank, negara Bahrain

3. Kuwait Finance House Bahrain, negara Bahrain

4. Khaleeji Commercial Bank, negara Bahrain

5. Ithmaar Bank, negara Bahrain

6. ABC Islamic Bank, negara Bahrain

7. Al Baraka Islamic Bank, negara Bahrain

8. Kuwait Finance House, negara Kuawait

9. Boubyan Bank, negara Kuwait

10. Kuwait International Bank, negara Kuwait

11. Ahli United Bank, negara Kuwait 
12. Masraf Al Rayan, negara Qatar

13. Qatar Islamic Bank, negara Qatar

14. Qatar International Islamic Bank, negara Qatar

15. Bank Al Jazira, negara Saudi Arabia

16. Alinma Bank, negara Saudi Arabia

17. Bank Albilad, negara Saudi Arabia

18. Al Rajhi Bank Saudi Arabia, negara Saudi Arabia

19. Abu Dhabi Islamic Bank, negara Uni Emirat Arab

20. Emirates Islamic Bank, negara Uni Emirat Arab

21. Ajman Islamic Bank, negara Uni Emirat Arab

22. Al Hilal Bank, negara Uni Emirat Arab

23. Dubai Islamic Bank, negara Uni Emirat Arab

24. Nor Islamic Bank, negara Uni Emirat Arab

25. Sharjah Islamic Bank, negara Uni Emirat Arab

26. Al Baraka Pakistan, negara Pakistan

27. Bank Islam, negara Pakistan

28. Buri Bank, negara Pakistan

29. Dubai Islamic Bank Pakistan, negara Pakistan

30. Meezan Bank, negara Pakistan

31. Al Arafah Bank, negara Bangladesh

32. First Security Bank, negara Bangladesh

33. ICB Islamic Bank, negara Bangladesh

34. Islamic Bank Bangladesh, negara Bangladesh

35. Shahialal Islamic Bank, negara Bangladesh

36. Jordan Dubai Bank, negara Jordan

37. Jordan Islamic Bank, negara Jordan

38. Al Baraka Egypt, negara Mesir

39. Faisal Islamic Bank, negara Mesir

40. Al Baraka Turki, negara Turki

41. Bank Asya, negara Turki

42. Kuveyt Turki, negara Turki

43. Turkiye Finance, negara Turki

\section{Metode Pengumpulan Data}

Metode pengumpulan data dalam penelitian ini adalah purposive sampling, yaitu metode pengambilan sampel yang dipilih berdasarkan pertimbangan yang berarti pemilihan sampel tidak dilakukan secara tidak acak yang informasinya diperoleh dengan pertimbangan tertentu, yaitu sampel yang diambil harus memenuhi kriteria-kriteria yang telah ditentukan agar sampel yang digunakan sesuai dengan tujuan dan hasil yang diperoleh lebih akurat.

Data sekunder yang digunakan adalah laporan keuangan yang diperoleh dari Maris Strategies \& The Banker tahun 2013 dan website resmi masing-masing bank.

\section{Definisi Operasional Variabel Penelitian}

Variabel yang digunakan dalam penelitian ini:

\section{Variabel Dependen}

Variabel Dependen adalah suatu variabel yang variasi nilainya dipengaruhi atau dijelaskan oleh variasi nilai variabel yang lain (Zainal, 2009).

Variabel Dependen pada penelitian ini adalah Islamic Social Reporting (ISR) yang diukur dengan menggunakan Indeks Islamic Social Reporting (ISR). Indeks Islamic Social Reporting (ISR) adalah alat ukur yang digunakan untuk mengukur pengungkapan tanggungjawab sosial pada perusahaan-perusahaan Islam.

Indeks Islamic Social Reporting (ISR) berisi kompilasi item-item standar Corporate Social Responsibility (CSR) yang ditetapkan oleh AAOIFI (Accounting and Auditing Organization for Islamic Financial Institutions) terdiri atas 10 (sepuluh) komponen dengan 45 (empat puluh lima) sub komponen.

Untuk mengetahui nilai Indeks Islamic Social Reporting (ISR) dapat dihitung dengan rumus sebagai berikut:

Nilai ISR $=\underline{\text { Jumlah Skor Informasi Yang Diungkapkan }}$ Jumlah Skor Maksimum

\section{Variabel Independen}

Variabel Independen adalah suatu variabel yang variasi nilainya akan mempengaruhi nilai variabel yang lain (Zainal, 2009). 
Variabel Independen dalam penelitian ini adalah:

\section{Jumlah Dewan Pengawas Syariah}

Jumlah Dewan Pengawas Syariah adalah banyaknya anggota dewan pengawas yang ditempatkan pada suatu insititusi keuangan Islam..

Kinerja Dewan Pengawas Syariah dapat dinilai dari banyaknya anggota dan harus memenuhi minimal 5 (lima) orang.

\section{Jumlah Dewan Pengawas Syariah bergelar Doctor}

Jumlah Dewan Pengawas Syariah bergelar Doctor adalah banyaknya anggota dewan pengawas yang memiliki gelar formal Doctor dan diharapkan memiliki pengetahuan yang cukup tentang keuangan pada umumnya dan keuangan Islam pada khususnya sehingga dapat memahami isuisu syariah yang terjadi.

\section{Reputasi Dewan Pengawas Syariah}

Reputasi Dewan Pengawas Syariah adalah banyaknya anggota dewan pengawas yang ditempatkan dalam suatu institusi keuangan Islam yang menguasai masalah terkait fiqh muamalah dan pengetahuan atau praktek di bidang transaksi keuangan.

\section{Rangkap Jabatan Dewan Pengawas Syariah}

Rangkap Jabatan Dewan Pengawas Syariah adalah dewan pengawas tidak hanya mengawasi satu institusi keuangan Islam tetapi juga dapat menjadi pengawas di institusi keuangan Islam yang lainnya.

\section{Non Performing Finance (NPF)}

Non Performing Finance (NPF) merupakan salah satu pengukuran dari resiko usaha bank yang menunjukkan besarnya resiko pembiayaan bermasalah yang ada pada suatu bank. Rumus perhitungan Non Performing Finance (NPF):

$\mathrm{NPF}=\underline{\text { Pembiayaan Bermasalah }} \times 100 \%$

Jumlah Pembiayaan

Return On Equity (ROE)

Hasil pengembalian ekuitas atau Return On Equity (ROE) atau rentabilitas modal sendiri merupakan rasio untuk mengukur laba bersih sesudah pajak dengan modal sendiri. Rasio ini menunjukkan efisiensi penggunaan modal sendiri.

Rumus perhitungan Return On Equity (ROE):

$\mathrm{ROE}=\underline{\text { Laba Setelah Bunga Dan Pajak }}$ x $100 \%$ Modal

\section{Return On Investment (ROI)}

Hasil pengembalian investasi atau Return On Investment (ROI) merupakan salah satu rasio yang digunakan untuk mengukur tingkat pengembalian investasi yang berasal dari aktiva atau modal.

Rumus perhitungan Return On Investment (ROI):

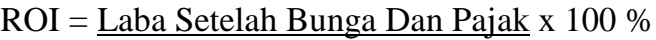
Total Asset

\section{Capital Adequacy Ratio (CAR)}

Capital Adequacy Ratio (CAR) merupakan rasio yang digunakan untuk mengukur permodalan dan cadangan penghapusan dalam menanggung perkreditan, terutama resiko yang terjadi karena bunga gagal ditagih.

Capital Adequacy Ratio (CAR) disebut juga sebagai rasio kecukupan modal, yaitu perbandingan antara modal bersih yang dimiliki oleh bank dengan total asset. Penentuan besarnya kebutuhan modal minimum yang dibutuhkan oleh bank syariah didasarkan pada aktiva tertimbang menurut resiko (ATMR). ATMR adalah faktor pembagi (denominator) dari CAR, sedangkan modal adalah faktor yang dibagi (numerator) untuk mengukur kemampuan modal menanggung resiko aktiva tersebut (Prima, 2014).

Rumus perhitungan Capital Adequacy Ratio (CAR):

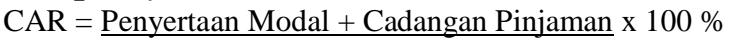
Kinerja Operasional Total Pinjaman

Rasio Operasional ini digunakan untuk mengukur efektivitas perbankan dalam menggunakan aktiva yang dimilikinya, membandingkan antara biaya dan pendapatan dari suatu perbankan, sehingga dapat diketahui kemampuan perbankan menghasilkan laba dari kegiatan 
usaha dengan memperhatikan biaya-biaya yang terjadi.

\section{Teknik Analisis Data}

Teknik analisis data dalam penelitian ini adalah analisis kualitatif dan kuantitatif. Teknik pengolahan data yang digunakan dalam penelitian ini adalah sebagai berikut:

\section{Uji Kualitas Data}

\section{Uji Normalitas}

Dalam penelitian ini, uji normalitas dilakukan dengan uji statistik Kolmogorov-Smirnov. Dalam uji One Sample Kolmogorov-Smirnov Test, residual yang mempunyai Asymp. Sig (2tailed) di bawah tingkat signifikan sebesar 0,05 (probabilitas < 0,05) diartikan bahwa variabel tersebut memiliki distribusi tidak normal dan sebaliknya.

\section{Uji Multikolinearitas}

Uji multikolinearitas bertujuan untuk menguji apakah model regresi ditemukan adanya korelasi antar variabel bebas (independen). Model regresi yang baik seharusnya tidak terjadi korelasi di antara variabel independen. Jika variabel independen saling berkorelasi, maka variabel-variabel ini tidak ortogonal. Multikolinearitas, dapat dilihat dari nilai tolerance dan lawannya variance inflation factor (VIF). Nilai cut-off yang umum dipakai untuk menunjukkan adanya multikolinearitas adalah nilai tolerance < 0,10 atau sama dengan nilai VIF $>10$.

\section{Uji Autokorelasi}

Dalam penelitian ini autokorelasi diuji dengan menggunakan metode uji Durbin Watson. Pengambilan keputusan ada atau tidaknya autokorelasi menurut Ghozali (2006) yaitu:
a. $0<$ nilai $\mathrm{DW}<\mathrm{dl}=$ ada autokorelasi positif
b. dl $\leq$ nilai $\mathrm{DW} \leq \mathrm{du}=$ tidak ada autokorelasi positif
c. du $<$ nilai DW $<4$-du = tidak ada autokorelasi

d. 4-du $\leq \mathrm{d} \leq 4$-dl = tidak ada korelasi negatif

e. 4 -dl $<$ nilai DW $<4=$ ada korelasi negatif

\section{Uji Heteroskedastisitas}

Model regresi yang baik adalah yang Homoskedastisitas atau tidak terjadi Heteroskedastisitas Metode lain yang dapat digunakan untuk mendeteksi heteroskedastisitas adalah metode Glejser, yaitu dengan cara meregresikan semua variabel independen dengan variabel dependen absolut residual dan dari hasil tersebut semua variabel harus memiliki nilai p-value yang lebih besar dari 0.05 untuk dapat dikatakan bahwa model tidak memiliki masalah heteroskedastisitas.

\section{Uji Regresi}

Persamaan regresinya adalah:

$Y=\alpha+\beta_{1} X_{1}+\beta_{2} X_{2}+\beta_{3} X_{3}+\beta_{4} X_{4}+\beta_{5} X_{5}+$ $\beta_{6} X_{6}+\beta_{7} X_{7}+\beta_{8} X_{8}+\beta_{9} X_{9}+\varepsilon$

Keterangan:

$\mathrm{Y} \quad=$ Indeks Islamic Social Reporting (ISR)

$\mathrm{X}_{1} \quad=$ Jumlah DPS

$\mathrm{X}_{2}=$ Jumlah DPS yang bergelar Doctor

$\mathrm{X}_{3} \quad=$ Reputasi DPS

$\mathrm{X}_{4} \quad=$ Rangkap jabatan DPS

$\mathrm{X}_{5}=\mathrm{NPF}$

$\mathrm{X}_{6}=\mathrm{ROE}$

$\mathrm{X}_{7}=\mathrm{ROI}$

$\mathrm{X}_{8} \quad=\mathrm{CAR}$

$\mathrm{X}_{9} \quad=$ Kinerja Operasional

$\alpha \quad=$ Konstanta

$\beta \quad=$ Koefisien Regresi

$\varepsilon=$ Error

\section{Koefisien Determinasi $\left(\mathbf{R}^{2}\right)$}

Nilai koefisien determinasi ini mencerminkan seberapa besar variasi dari variabel terikat (Y) dapat diterangkan oleh variabel bebas $(\mathrm{X})$.

Jika $p$-value $<\alpha(0,05)$ maka $\mathrm{H}_{0}$ ditolak dan $\mathrm{H}_{1}$ diterima, dapat disimpulkan bahwa dengan tingkat signifikansi $\alpha$ secara 
individual variabel-variabel independen berpengaruh secara signifikan terhadap variabel indeks ISR.

\section{HASIL DAN PEMBAHASAN}

Hasil penelitian menunjukkan bahwa jumlah DPS bergelar doctor, rangkap jabatan DPS, CAR dan Operasional berpengaruh terhadap indeks Islamic Social Reporting (ISR). Jumlah DPS, reputasi DPS, NPF, ROE dan ROI tidak berpengaruh terhadap indeks Islamic Social Reporting (ISR).

Jumlah DPS tidak menunjukkan pengaruh yang signifikan terhadap indeks Islamic Social Reporting (ISR). Jumlah DPS yang besar tidak menunjukkan bahwa kinerja bank Islam baik. Semakin banyak jumlah anggota Dewan Pengawas Syariah tidak menunjukkan adanya pengawasan yang baik atas kepatuhan bank syariah Islam karena bukan banyaknya anggota DPS melainkan kualitas anggota DPS.

Jumlah DPS bergelar doctor menunjukkan pengaruh yang signifikan terhadap indeks Islamic Social Reporting (ISR). Jumlah DPS bergelar doctor menunjukkan bahwa kinerja bank Islam baik. Semakin banyak jumlah anggota Dewan Pengawas Syariah bergelar doctor akan meningkatkan kapasitas monitoring terhadap Dewan Pengawas Syariah sehingga akan mendorong kinerja yang lebih baik karena dewan lebih memiliki pengalaman, kepakaran, pengalaman, keahlian, dan jaringan profesional serta sosial yang lebih baik.

Reputasi DPS tidak menunjukkan pengaruh yang signifikan terhadap indeks Islamic Social Reporting (ISR). Kualifikasi anggota Dewan Pengawas Syariah pada perbankan syariah harus menguasai masalah terkait fiqh muamalah dan pengetahuan atau praktek di bidang transaksi keuangan. Kualifikasi ini sejalan dengan apa yang disarankan oleh para ahli dalam hukum Islam. Akan tetapi kualifikasi menguasai masalah terkait fiqh dan transaksi keuangan saja tidak cukup karena kinerja anggota DPS berdasarkan tanggungjawab DPS dalam menjalankan tugasnya. Seperti halnya dalam diskualifikasi dari anggota jika mereka tidak menunaikan tugas dengan baik (misconduct)

Rangkap jabatan DPS menunjukkan pengaruh yang signifikan terhadap indeks Islamic Social Reporting (ISR). Dewan Pengawas Syariah dapat bertindak sebagai pengawas syariah tidak hanya pada satu bank saja, namun boleh bertindak sebagai pengawas syariah di lebih dari satu bank atau lembaga keuangan syariah lainnya.

Non Performing Finance (NPF) tidak menunjukkan pengaruh yang signifikan terhadap indeks Islamic Social Reporting (ISR). Kredit bermasalah merupakan salah satu indikator kunci untuk menilai kinerja bank syariah. Non Performing Finance (NPF) yang lebih besar dalam suatu periode secara tidak langsung memberikan penurunan laba untuk periode yang sama.

Return On Equity (ROE) tidak menunjukkan pengaruh yang signifikan terhadap indeks Islamic Social Reporting (ISR). Bank yang mempunyai profitabilitas tinggi belum tentu banyak melakukan aktivitas sosial karena perusahaan lebih berorientasi pada laba semata.

Return On Investment (ROI) tidak menunjukkan pengaruh yang signifikan terhadap indeks Islamic Social Reporting (ISR). Semakin tinggi Return On Investment (ROI) belum tentu semakin besar pengungkapan informasi sosial. Secara spesifik terhadap indeks Islamic Social Reporting (ISR), profitabilitas tidak mempunyai pengaruh positif signifikan terhadap tingkat pengungkapan tanggung jawab sosial yang sesuai dengan prinsip Islam.

Capital Adequacy Ratio (CAR) menunjukkan pengaruh yang signifikan terhadap indeks Islamic Social Reporting (ISR). Hal ini mengindikasikan bahwa tingkat kecukupan modal bank syariah menjadi salah satu faktor penting yang 
dipertimbangkan oleh bank syariah dalam melakukan pengungkapan Corporate Social Responsibility (CSR). Jika kecukupan modal bank syariah baik maka bank akan lebih mampu untuk melaksanakan Corporate Social Responsibility (CSR) yang secara otomatis akan mengungkapnya juga pada laporan tahunannya.

Rasio Operasional menunjukkan menunjukkan pengaruh yang signifikan terhadap indeks Islamic Social Reporting (ISR). Rasio Operasional ini membandingkan antara biaya dan pendapatan dari suatu bank syariah, sehingga dapat diketahui kemampuan bank syariah menghasilkan laba dari kegiatan usaha dengan memperhatikan biaya-biaya yang terjadi. Hal tersebut menunjukkan kinerja operasional bank syariah. Dengan demikian, semakin sedikit biaya yang dikeluarkan, maka akan meningkatkan pendapatan dan menghasilkan laba yang tinggi pula, sehingga menunjukkan kinerja bank syariah yang baik.

\section{Tabel 2. Ringkasan Hasil Analisis}

\begin{tabular}{|l|c|c|}
\hline \multicolumn{1}{|c|}{ Model } & Coefficient & Sig \\
\hline (Constant) & & 0,316 \\
\hline Jumlah DPS & 0,272 & 0,167 \\
\hline $\begin{array}{l}\text { Jumlah DPS } \\
\text { bergelar } \\
\text { doctor }\end{array}$ & $-0,012$ & 0,917 \\
\hline $\begin{array}{l}\text { Reputasi } \\
\text { DPS }\end{array}$ & $-0,224$ & 0,610 \\
\hline $\begin{array}{l}\text { Rangkap } \\
\text { jabatan DPS }\end{array}$ & $-0,197$ & 0,128 \\
\hline NPF & $-0,285$ & 0,190 \\
\hline ROE & 0,093 & 0,450 \\
\hline ROI & $-0,028$ & 0,821 \\
\hline CAR & 0,190 & 0,152 \\
\hline $\begin{array}{l}\text { Kinerja } \\
\text { Operasional }\end{array}$ & 0,428 & 0,220 \\
\hline
\end{tabular}

\section{PENUTUP}

\section{Kesimpulan}

Jumlah DPS bergelar doctor, rangkap jabatan DPS, CAR dan Operasional berpengaruh terhadap indeks
Islamic Social Reporting (ISR). Jumlah DPS, reputasi DPS, NPF, ROE dan ROI tidak berpengaruh terhadap indeks Islamic Social Reporting (ISR).

\section{Implikasi Penelitian}

Impikasi dari penelitian ini adalah:

a. Pengukuran kinerja bank syariah sebaiknya tidak hanya berfokus pada kinerja profitabilitas saja, tetapi perlu mengukur kualitas dan kemampuan dari Dewan Pengawas Syariah dalam melakukan fungsi di bank syariah

b. Kualitas, peran dan fungsi Dewan Pengawas Syariah pada perbankan syariah di kawasan Timur Tengah dirasakan sudah cukup baik, yang dapat dilihat dari banyaknya jumlah Dewan Pengawas Syariah yang bergelar doctor dan rangkap jabatan oleh Dewan Pegawas Syariah.

c. Kecukupan modal perbankan syariah di kawasan Timur Tengah mampu mengakomodir kebutuhan sosial.

\section{Keterbatasan Penelitian}

a. Penelitian ini terdapat subyektivitas dalam pemberian nilai indeks Islamic Social Reporting (ISR).

b. Periode pengamatan ini cukup pendek terbatas pada periode 2012 sampai dengan 2014.

c. Jumlah sampel bank yang digunakan Data yang dijadikan sampel sejumlah 43 (empat puluh tiga) bank syariah tetapi hanya bisa terpenuhi 30 (tiga puluh) bank syariah.

\section{Saran}

a. Penelitian selanjutnya sebaiknya mengembangkan item-item indeks Islamic Social Reporting (ISR) agar memiliki batasan jelas untuk setiap indikatornya sehingga peneliti mudah dalam menginterpretasikan maksud item-item tersebut.

b. Penelitian selanjutnya sebaiknya menggunakan periode yang lebih panjang untuk dapat menganalisis 
lebih mendalam terhadap pengaruh variabel-variabelnya.

c. Penelitian selanjutnya sebaiknya menambah variabel-variabel lain.

\section{DAFTAR PUSTAKA}

AAOIFI (2002). Accounting, Auditing, and Governance Standards for Islamic Financial Institutions. Bahrain.

Ahmed, I.E. The Contents of Social Disclosure : A Survey of The UAE Islamic Bank's Reports.

Farook, S., Hassan M.K., Lanis. R. (2011). Determinants Of Corporate Social Responsibility Disclosure : The Case Of Islamic Banks (Vol. 2, pp. 114141). Journal Of Islamic Accounting And Business Research.

Farook., S., \& Roman L. (2005). Banking On Islam? Determinants Of Social Responsibility Disclosure 354-388

Fitria, S. \& Hartanti, D. (2010). Islam Dan Tanggungjawab Sosial : Studi Perbandingan Pengungkapan Berdasarkan Global Reporting Initiative Indeks Dan Islamic Social Reporting Indeks. Simposium Nasional Akuntansi XVIII Purwokerto

Haniffa, R., (2002) Social Reporting Disclosure : An Islamic Perspective. Indonesian Management And Accounting Research 128-146

Junaidi., (2014). Analisis Pengungkapan Tanggungjawab Sosial Perbankan Syariah Berdasarkan Islamic Social Reporting (ISR) Studi Kasus Pada 4 Bank Syariah Di Asia Periode 2011 2012. Tesis Universitas Islam Indonesia Yogyakarta.

Kholid, M.N. (2014). Pengaruh Dana Syirkah Temporer, Dewan Komisaris, Islamic Governance, Dan Komite Audit Terhadap Kinerja Maqasid Syariah Bank Syariah. Tesis Universitas Islam Indonesia, Yogyakarta.

Muhammad, R. (2010). Persepsi User Dan Preparer Laporan Keuangan Terhadap Pelaporan Sosial Perbankan Islam di Malaysia.
Mustafa, Z. (2009). Edisi Pertama. Mengurai Variabel Hingga Instrumentasi. Yogyakarta: Graha Ilmu.

Muttakin, Mohammad. B., Shahih. U. (2012). Corporate Governance and Bank Performance: Evidence From Bangladesh. Corporate Board: Role, Duties \& Composition 1-8

Rahayu, B.S. (2014). Pengaruh CAR, NPF, NIM, FDR, Dan Pengungkapan CSR Terhadap ROA Pada Perbankan Umum Syariah Di Indonesia Tahun 2008-2012. Tesis Universitas Sebelas Maret Surakarta.

Rahman, A.A. \& Bukair. (2013). The Influence Of The Shariah Supervision Board On Corporate Social Responsibility Disclosure By Islamic Banks Of Gulf Co-Operation Council Countries. Asian Journal Of Business And Accounting 6 (2)

Saeed, A. (2008). Cetakan Ketiga. Bank Islam Dan Bunga Studi Kritis Larangan Riba Dan Interpretasi Kontemporer (14-15). Yogyakarta: Pustaka Pelajar.

Shariah Governance Framework (2010)

Shofiani, P. (2014). Analisis Faktor-Faktor Yang Mempengaruhi Income Smoothing Perbankan Islam (Studi Empiris Pada Bank-Bank Islam Di Malaysia Periode 2011-2013). Tesis Universitas Islam Indonesia, Yogyakarta. 